\title{
Asian aridification linked to the first step of the Eocene-Oligocene climate Transition (EOT) in obliquity-dominated terrestrial records (Xining Basin, China)
}

\author{
G. Q. Xiao ${ }^{1,2}$, H. A. Abels ${ }^{3}$, Z. Q. Yao ${ }^{1}$, G. Dupont-Nivet ${ }^{4}$, and F. J. Hilgen ${ }^{3}$ \\ ${ }^{1}$ State Key Laboratory of Loess and Quaternary Geology, Institute of Earth Environment, Chinese Academy of Sciences, \\ P.O. Box 17, Xian, 710075, China \\ ${ }^{2}$ Key Laboratory of Biogeology and Environmental Geology of Ministry of Education, China University of Geosciences, \\ Wuhan, 430074, China \\ ${ }^{3}$ Stratigraphy/Paleontology, Dept. of Earth Sciences, Utrecht University, Utrecht, The Netherlands \\ ${ }^{4}$ Paleomagnetic Laboratory "Fort Hoofddijk”, Dept. of Earth Sciences, Utrecht University, Utrecht, The Netherlands
}

Received: 21 March 2010 - Published in Clim. Past Discuss.: 20 April 2010

Revised: 22 June 2010 - Accepted: 9 July 2010 - Published: 29 July 2010

\begin{abstract}
Asian terrestrial records of the Eocene-Oligocene Transition (EOT) are rare and, when available, often poorly constrained in time, even though they are crucial in understanding the atmospheric impact of this major step in Cenozoic climate deterioration. Here, we present a detailed cyclostratigraphic study of the continuous continental EOT succession deposited between $\sim 35$ to $33 \mathrm{Ma}$ in the Xining Basin at the northeastern edge of Tibetan Plateau. Lithology supplemented with high-resolution magnetic susceptibility (MS), median grain size (MGS) and color reflectance $\left(a^{*}\right)$ records reveal a prominent $\sim 3.4 \mathrm{~m}$ thick basic cyclicity of alternating playa gypsum and dry mudflat red mudstones of latest Eocene age. The magnetostratigraphic age model indicates that this cyclicity was most likely forced by the 41kyr obliquity cycle driving oscillations of drier and wetter conditions in Asian interior climate from at least 1 million year before the EOT. In addition, our results suggest a duration of $\sim 0.9 \mathrm{Myr}$ for magnetochron $\mathrm{C} 13 \mathrm{r}$ that is in accordance with radiometric dates from continental successions in Wyoming, USA, albeit somewhat shorter than in current time scales. Detailed comparison of the EOT interval in the Tashan section with marine records suggest that the most pronounced lithofacies change in the Xining Basin corresponds to the first of two widely recognized steps in oxygen isotopes across the EOT. This first step precedes the major and second step (i.e. the base of Oi-1) and has recently been reported to be mainly related to atmospheric cooling rather than ice vol-
\end{abstract}

Correspondence to: $\mathrm{H}$. A. Abels (abels@geo.uu.nl) ume growth. Coincidence with lithofacies changes in our Chinese record would suggest that the atmospheric impact of the first step was of global significance, while the major ice volume increase of the second step did not significantly affect Asian interior climate.

\section{Introduction}

The Eocene-Oligocene Transition (EOT) encompasses the most pronounced cooling event during Cenozoic climate deterioration (Miller et al., 1991; Zachos et al., 1996, 2001; Lear et al., 2000, 2008). It was accompanied by the expansion of ice sheets on the Antarctic continent (e.g. Zachos et al., 2001; Coxall et al., 2005; Lear et al., 2008), a global sealevel drop (e.g. Miller et al., 1991; Katz et al., 2008), a declining atmospheric $\mathrm{CO}_{2}$ concentration (Pearson and Palmer, 2000; Pearson et al., 2009), a deepening of the calcite compensation depth (Coxall et al., 2005; Tripati et al., 2005), and a biotic reorganization (e.g. Meng and McKenna, 1998; Ivany et al., 2003; Hansen et al., 2004; Pearson et al., 2008). Geological records from different latitudes indicate significant cooling during this transition (Zachos et al., 1996; Retallack et al., 2004; Zanazzi et al., 2009; Katz et al., 2008; Lear et al., 2008; Schouten et al., 2008; Liu et al., 2009), implying that this phenomenon had a global rather than regional impact on climate. Climate modeling results and ocean sediment records have demonstrated that the decline of $p \mathrm{CO}_{2}$ and a peculiar orbital configuration were the primary factors responsible for this transition (Coxall et al., 2005; DeConto and Pollard, 2003; DeConto et al., 2008). Ocean sediment

Published by Copernicus Publications on behalf of the European Geosciences Union. 
records further show that this transition occurred in two or possibly three steps within $\sim 400 \mathrm{kyr}$ (Coxall et al., 2005; Katz et al., 2008; Lear et al., 2008; Pearson et al., 2008). Age models for paleoclimatic records across the EOT have increased in both resolution and accuracy, which is crucial for unraveling cause and effect during such a complicated transitional interval. Sediments recovered during ODP Leg 199 (Pälike et al., 2006) and the Tanzanian Drilling Project (TDP) (Pearson et al., 2008; Lear et al., 2008) are excellent examples of this approach. The coming years are expected to shed more light as multiple continuous carbonate-rich records have been recovered during IODP Leg 320. Equally promising are continental EOT records that would allow direct evaluation of modeled atmospheric climate, which is currently mostly based on data from the oceanic domains. Reliable global marine to continental comparison requires increased age control at orbital scale resolution of key continental successions such as in North America (e.g. Zanazzi et al., 2009), in the UK (Gale et al., 2006; Hooker et al., 2009), and in China (Dupont-Nivet et al., 2007).

The Eocene to Early Miocene lacustrine records from the Xining Basin at the northeastern margin of the Tibetan Plateau (Fig. 1a) provide an excellent opportunity to investigate climate change during the EOT (Dai et al., 2006; Dupont-Nivet et al., 2007). The Eocene successions consist of red mudstones with intercalations of gypsum and gypsiferous layers (Qinghai Bureau of Geology and Mineral Resources, 1985). Detailed lithofacies analyses of the Xiejia and Shuiwan sections showed that gypsum/gypsiferous layers were formed in shallow playa lake settings, while mudstone layers developed in distal alluvial fan and dry mudflat environments (Dupont-Nivet et al., 2007). Dupont-Nivet et al. (2007) interpreted gypsum intercalations within red mudstones to indicate periods of significantly higher water supply. They further showed that the regional disappearance of intercalated gypsum beds from red mudstone stratigraphy coincides with the EO-boundary based on a stratigraphic analysis of the Xiejia and Shuiwan sections. This coincidence was interpreted as to reflect regional aridification related to climate change. Their magnetostratigraphic age model further suggested that the regular lithofacies alternations between mudstone and gypsum in the Late Eocene were forced by the 100 -kyr eccentricity cycle. These results provide the framework for a more detailed analysis of the E/O-boundary interval. Here we present a cyclostratigraphic study of the upper Eocene succession in the Xining Basin enabling a comparison with recently refined marine records. We investigate a well-exposed section near the village of Tashan (TS section; Fig. 1) using high-resolution magnetic susceptibility (MS), median grain size (MGS) and color reflectance $\left(a^{*}\right)$ records, regional correlation of lithostratigraphy, and detailed magnetostratigraphic time control.
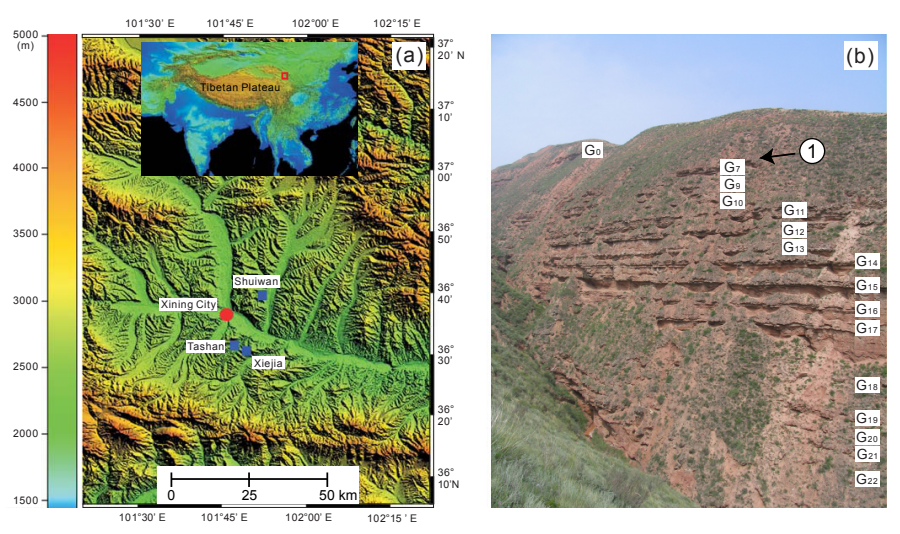

Fig. 1. (a) Location of the Tashan (TS), the Xiejia, and the Shuiwan sections, (b) View of the TS section. The end of regular, thick gypsum-mudstone cyclicity occurs above bed $\mathrm{G}_{7}$ indicated as event 1 (see Fig. 7).

\section{Geological setting}

The Xining Basin is part of a larger Paleocene-Miocene basin system characterized by upward fining sediments associated with decreasing rates of accumulation $(1-10 \mathrm{~cm} / \mathrm{kyr})$ attributed to regional post-rift thermal subsidence subsequent to Mesozoic extension (Dupont-Nivet et al., 2004; Horton et al., 2004). The stratigraphic base is found disconformable on the Upper Cretaceous Minhe group. This basal relationship extends to the east in the adjacent Lanzhou Basin where thicker conglomeratic series are found unconformable on folded Cretaceous rocks suggesting post Cretaceous tectonism east of the Xining Basin followed by regional subsidence and basin initiation or re-activation (Zhai and Cai, 1984). Magnetostratigraphic dating of the particularly well-developed $>1000 \mathrm{~m}$ thick Cenozoic stratigraphy of the Xining Basin indicates sub-continuous deposition between $\sim 52 \mathrm{Ma}$ to $17 \mathrm{Ma}$ (Dai et al., 2006). The stratigraphy consists of basal sandy successions (Qijiachuan formation) overlain by red mudstones with distinctive gypsiferous intercalations (Honggou and Mahalagou formations) overlain by light brown to yellow mudstones with occasional sandy lenses (Xiejia, Chetougou and Xianshuihe formations). Apart for the disappearance of gypsum intercalation precisely correlated to the $34 \mathrm{Ma}$ Eocene-Oligocene climate transition (Dupont-Nivet et al., 2007), deposition is virtually undisturbed with slow accumulation (average $2.2 \mathrm{~cm} / \mathrm{kyr}$ ) until $17 \mathrm{Ma}$ suggesting that important deformation did not affect the Xining Basin until that time. A post$17 \mathrm{Ma}$ age is hence indicated for the observed deformation of the strata by a set of regional E-W and local NW-SE structures.

The TS section $\left(101^{\circ} 50^{\prime} \mathrm{E}, 36^{\circ} 33^{\prime} \mathrm{N}\right)$ is located $\sim 3 \mathrm{~km}$ west of the Xiejia and $\sim 13 \mathrm{~km}$ south of the Shuiwan section (Dai et al., 2006; Dupont-Nivet et al., 2007) in the Xining 


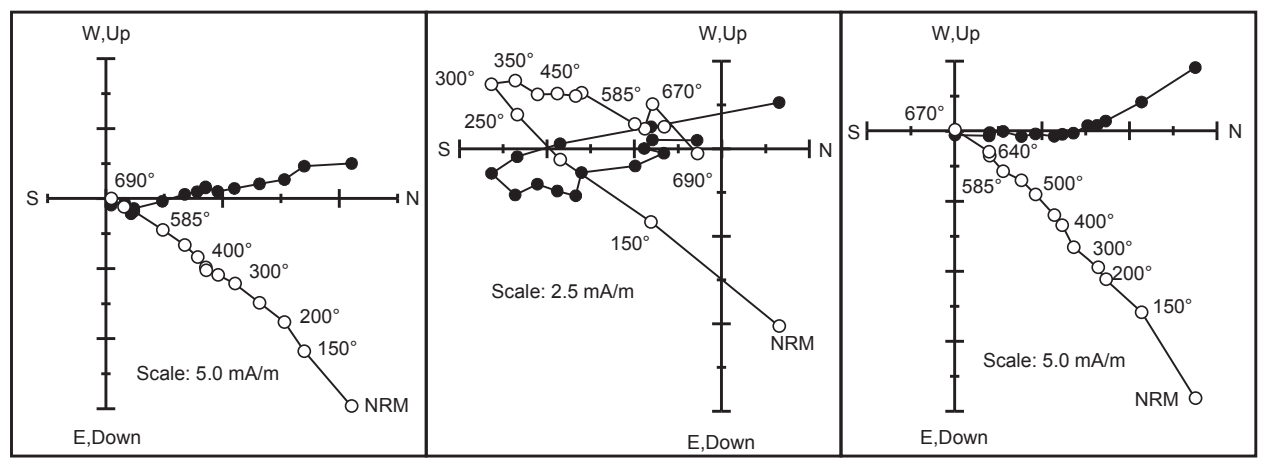

(a) 07 TS44 (464.7m, C13n)

(b) 07 TS49 (469.7m, C13n-1)

(c) $07 \mathrm{TS} 55$ (475.7m, C13n)

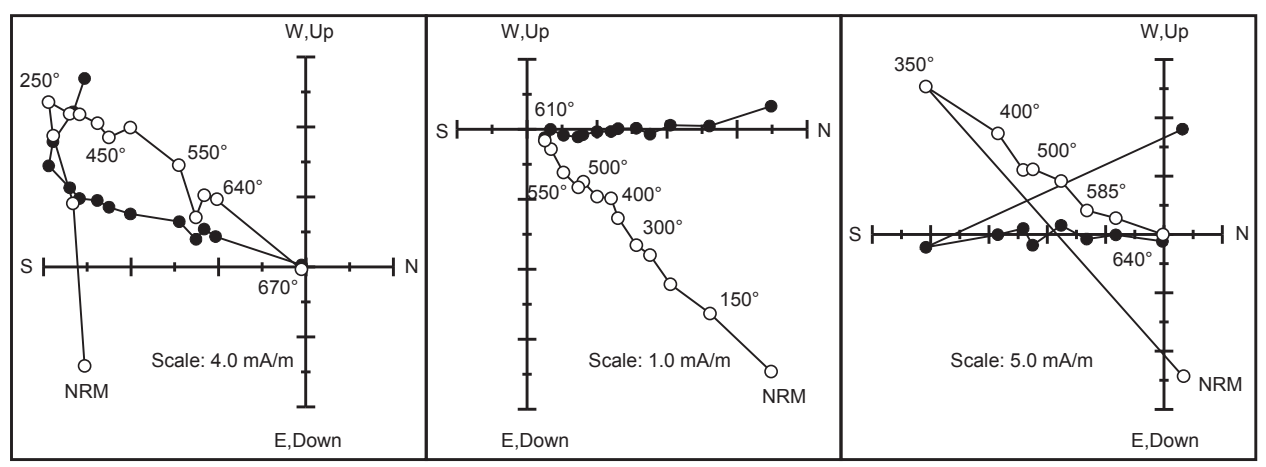

(d) $07 \mathrm{TS} 70(490.7 \mathrm{~m}, \mathrm{C} 13 \mathrm{r})$

(e) $07 \mathrm{TS} 127$ (547.7m, C15n)

(f) $07 \mathrm{TS} 132.25$ (553m, C15r)

Fig. 2. Orthogonal (Zijderveld) vector plots of representative thermal demagnetization behaviors of specimens from the TS section (a-f). The solid and open circles represent vector end-points projected onto horizontal and vertical planes, respectively. NRM is the natural remanent magnetization before demagnetization. Numbers indicate temperature steps in degrees Celsius. Between parentheses the meterlevels and chron labels are given which refer to stratigraphic position in the Tashan section and the magnetic chron the samples belong to after correlation to the time scale, respectively (see Fig. 4).

Basin (Fig. 1a). The TS section measures $103.3 \mathrm{~m}$ in thickness, and is composed of red mudstones with 24 muddy gypsum or gypsiferous mud layers labeled $\mathrm{G}_{0} \sim \mathrm{G}_{23}$ (Fig. 1b). No indications for unconformities were observed in the TS section. The succession is clearly correlative to previously studied Xiejia and Shuiwan parallel sections (Dupont-Nivet et al., 2007), which include the E/O climate transition.

\section{Magnetostratigraphy}

\subsection{Methods}

A total of 306 oriented samples in the TS section with a sample spacing of $25 \mathrm{~cm}$ were paleomagnetically analyzed. No gypsum or gypsiferous layers were sampled, as these are devoid of magnetic minerals. All samples were subjected to progressive thermal demagnetization in a MMTD-80 thermal demagnetizer. Thermal demagnetization up to $690^{\circ} \mathrm{C}$ included a maximum of 15 steps with intervals of $20-50^{\circ} \mathrm{C}$. Remanence measurements were made using a $2 \mathrm{G}-760 \mathrm{U}$ Channel system and performed in the Paleomagnetism and
Geochronology Laboratory of the Institute of Geology and Geophysics, Chinese Academy of Sciences, Beijing, China, where all equipment is installed in a magnetically shielded room (background field $<300 \mathrm{nT}$ ).

\subsection{Results}

Demagnetization results were evaluated on stereographic projections and vector end point orthogonal diagrams (Fig. 2a-f). For most samples, after removing a viscous magnetization component below $250-300^{\circ} \mathrm{C}$, a Characteristic Remanent Magnetization (ChRM) component was successfully isolated between $300^{\circ} \mathrm{C}$ and $620^{\circ} \mathrm{C}$ (some up to $670^{\circ} \mathrm{C}$ ) with most of the remanence demagnetized at $\sim 585^{\circ} \mathrm{C}$. This suggests a combination of magnetite and some hematite similarly to the nearby Xiejia and Shuiwan sections (Dai et al., 2006; Dupont-Nivet et al., 2007). A small number of samples (14\%), mostly from gypsiferous and/or green beds, showed unstable demagnetization trajectories such that ChRM directions could not be isolated. For the remaining samples, the ChRM directions were calculated by principal component analyses (Kirschvink, 1980) on a 
(a) ChRM directions

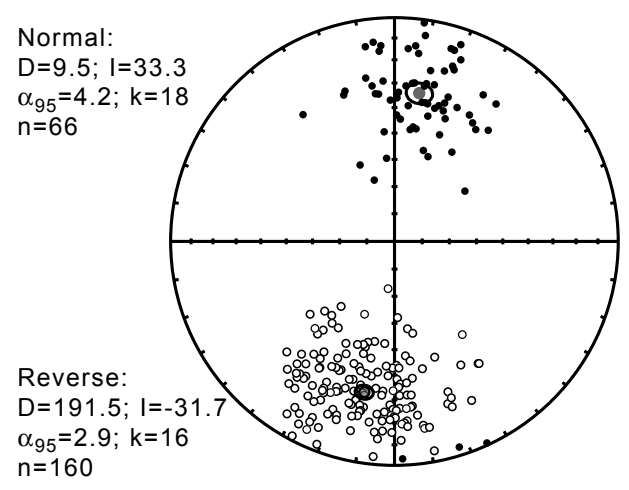

(b) Positive reversals test (Tauxe, 1998)
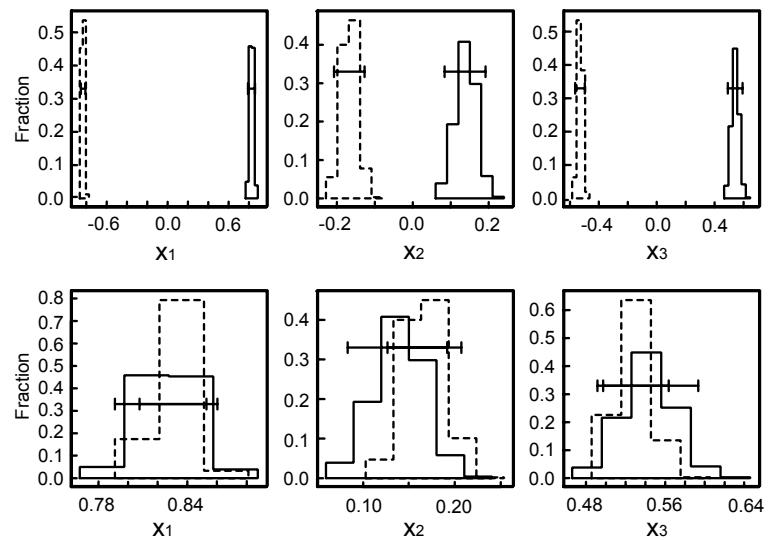

Fig. 3. Equal-area projections of characteristic remanent magnetization (ChRM) directions (downward (upward) directions are shown as solid (open) circles) of 226 samples from the TS section (a) and reversals test (b). The angle between the mean of the normal polarity set and the mean of the reverse polarity set is $2.3^{\circ}$. The critical angle is $5.2^{\circ}$. The probability of exceeding this angle is 0.558 resolved between $5^{\circ}$ and $10^{\circ}$ thus defining a B-class reversals test (McFadden and McElhinny, 1990) and a positive reversals test at 95\% confidence as indicated in lower panel (Tauxe, 1998).

minimum of four consecutive steps. ChRM directions with maximum angular deviation (MAD) above $15^{\circ}$ were systematically rejected. To remove outliers and transitional directions, we further rejected normal and reverse ChRM directions with Virtual Geomagnetic Poles (VGP) less than $45^{\circ}$ from the mean normal and reverse VGP respectively. Remaining ChRM directions cluster in antipodal normal and reverse polarity orientations (Fig. 3). This resulted in a set of 66 normal and 160 revered polarity ChRM directions passing the reversals test (Fig. 3). This strongly suggests a primary origin of the magnetization and enables us to confidently establish a polarity zonation through the section. The ChRM directions of 226 samples (see Supplementary Table) are used to calculate the virtual geomagnetic pole (VGP) latitudes and define the geomagnetic polarity zones.

Polarity zones are defined by at least two successive levels of similar polarity. This yields four reversed polarity zones (R1 to R4, Fig. 4) and four normal zones (N1 to N4). The obtained pattern is strikingly similar to that previously found in the same stratigraphic interval in the Xiejia and Shuiwan sections (Dupont-Nivet et al., 2007) with the exception of a short reversed interval (R2) defined by two reversed levels (Fig. 4).

\subsection{Correlation to the GPTS}

Our magnetostratigraphy is in line with the previous studies of the Xiejia and Shuiwan sections (Dai et al., 2006; Dupont-Nivet et al., 2007, Fig. 5) and corresponds to the interval of $\mathrm{C} 12 \mathrm{r}$ to $\mathrm{C} 16 \mathrm{n}$. $1 \mathrm{n}$ in the geomagnetic polarity time scale of Gradstein et al. (2004) (hereinafter referred to as GTS04). The correlation is not only based on the magne- tostratigraphy presented here, but on an integrated set of data of different and much longer sections, in particular the Xiejia and Shuiwan sections extending from the Eocene up into the Miocene (Dai et al., 2006; Dupont-Nivet et al., 2007). An extensive justification of the correlation is already published in Dupont-Nivet et al. (2007). This primarily relies on the distinctive pattern of two long reversed polarity zones separated by a shorter normal zone that unequivocally correlates with $\mathrm{C} 13 \mathrm{n}$. In addition, the pattern fit is corroborated by smaller polarity zones, steady accumulation rates and some age diagnostic fossils found in the Eocene and lower Miocene part of the sampled sections. Alternative correlations are indeed investigated in Dupont-Nivet et al. (2007) but the C12r-C16n. 1n correlation of the interval considered here remains robust whatever alternative is considered (see in particular the methods section of Dupont-Nivet et al., 2007). The short reversed polarity zone R2 in our section may correlate with cryptochron C13n-1, which is based on a tiny wiggle observed in marine magnetic anomaly profiles (Cande and Kent, 1995). This is supported by the low VGP latitudes observed within this interval (see Supplementary Table) that may result from the recording of transitional geomagnetic directions. However, this cryptochron requires confirmation by other high-resolution magnetostratigraphic records of $\mathrm{C} 13 \mathrm{n}$.

\subsection{EOT interval in Xining Basin}

Regional climate change associated with the EOT has been previously placed at the top of the uppermost gypsum bed that is correlatable at the basin scale (Fig. 5; Dupont-Nivet et al., 2007). Therefore, we first establish basin-wide lithological correlations from the TS section to the nearby Xiejia 


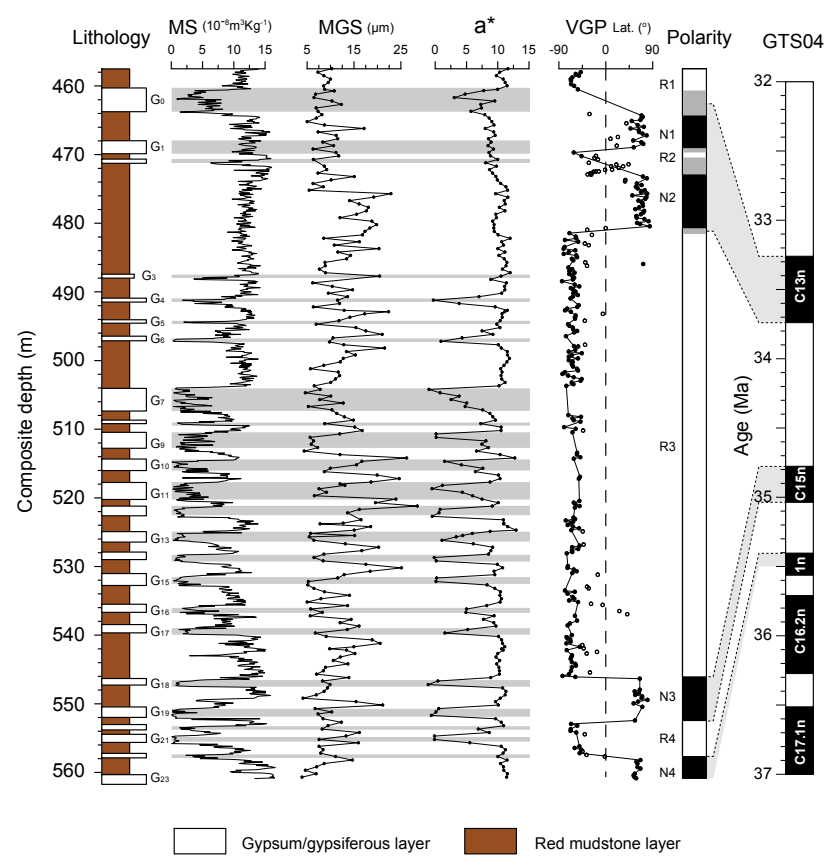

Fig. 4. To the left, lithostratigraphy of the TS section showing dominant red mudstones with intercalated gypsum and gypsiferous mudstone beds arbitrarily labeled $\mathrm{G}_{0}$ to $\mathrm{G}_{23}$. Composite depth scale refers to a much longer section not shown here. In the middle are shown the magnetic susceptibility (MS), median grain size (MGS), and redness reflectance $\left(a^{*}\right)$ records with grey bars indicating gypsum bed intercalations. To the right, VGP latitude results from paleomagnetic analysis with full (open) dots indicating reliable (rejected) VGP latitude (see text). Polarity - interpreted polarity zones with black (white) for normal (reversed) result and grey for uncertain result. Normal (reversed) polarity zones labeled N1 to N4 (R1 to R4).

and Shuiwan sections of Dupont-Nivet et al. (2007) based on magnetostratigraphic correlations followed by correlating patterns in lithology (Fig. 5). In the top of chron C13r, beds $\mathrm{G}_{4}$ to $\mathrm{G}_{6}$ of the TS section are readily correlated to beds $\mathrm{G}_{-} 0$ to $\mathrm{G}_{2} 2$ in the Xiejia and Shuiwan sections. Below, the interval from $\mathrm{G}_{7}$ to $\mathrm{G}_{17}$ in TS most likely correlate with beds G_3 to G_11 in Xiejia and Shuiwan. Around chron C15n, the intercalated gypsum beds reveal less characteristic patterns, though the thick beds $\mathrm{G}_{19}$ and $\mathrm{G}_{21}$ correlate best with $\mathrm{G}_{-} 15$ and G_17. Following these correlations, the marked MS minimum at $\sim 543 \mathrm{~m}$ in the TS section should be correlated to bed G_12 in the Shuiwan section (see Sect. 4.2 for proxy analysis, Figs. 4 and 5). Figure 5 thus shows dashed lines representing lithological correlations of stratigraphic intervals and cycle numbers representing the bed-to-bed correlation coeval gypsum beds in the three sections.

The resulting lithological correlations show that prominent cycle patterns below $\mathrm{G}_{4}$ in the TS section are regionally correlatable with minor differences, which occur especially in intervals with less pronounced gypsum beds. Above $\mathrm{G}_{4}$, a

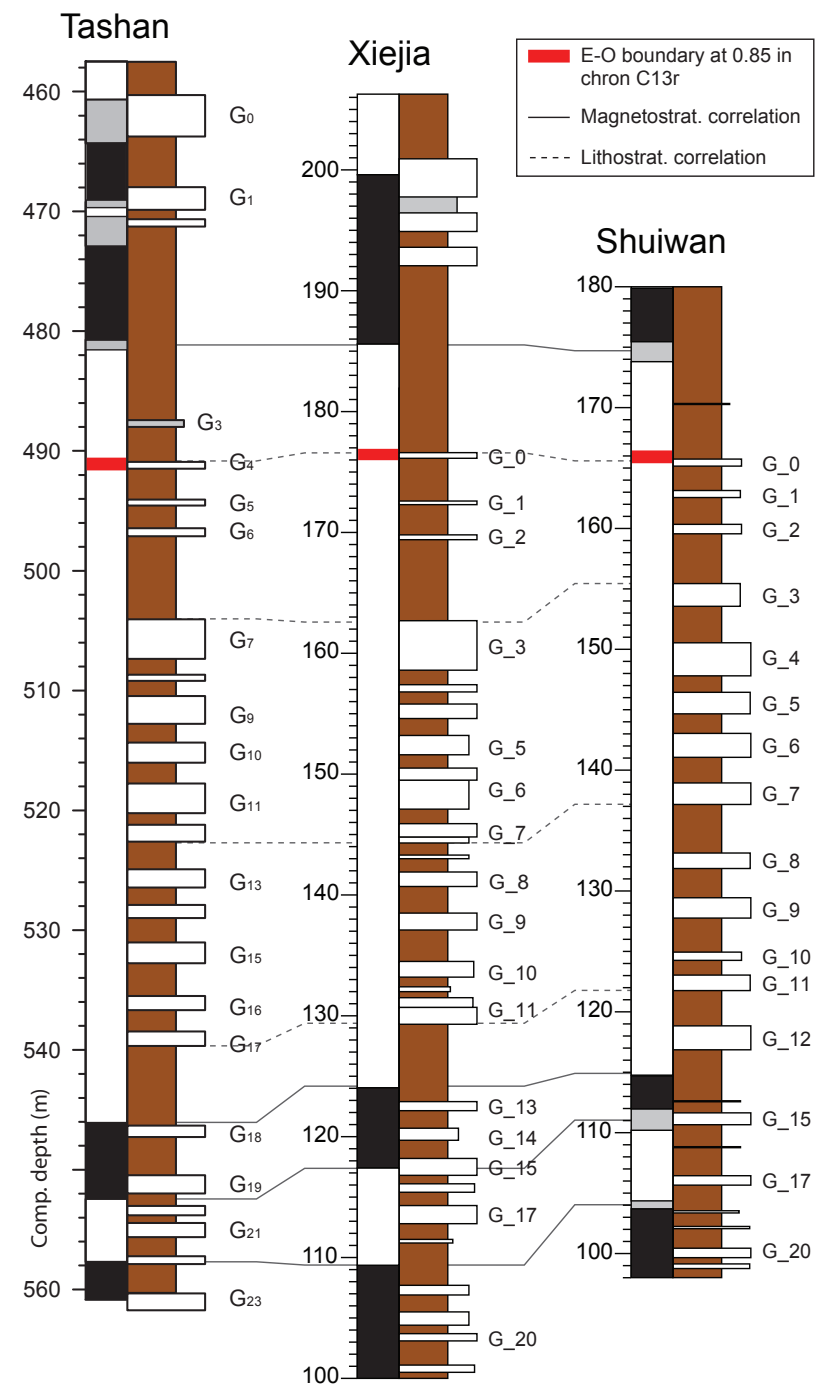

Fig. 5. Magnetostratigraphic and lithostratigraphic correlation between the Tashan (TS) section of this study and the Xiejia (XJ) and Shuiwan (SW) sections from Dupont-Nivet et al. (2007). Indicated are the gypsum bed labels used here and in Dupont-Nivet et al. (2007). Lithostratigraphies of the XJ and SW sections have been slightly adjusted according to more detailed sedimentologic descriptions. Red lines indicate the position of the Eocene-Oligocene boundary at $85 \%$ through $\mathrm{C} 13 \mathrm{r}$ in the respective magnetostratigraphies of the three sections. Note that the estimated position of the EOB coincides with the end of regular and regional correlatable gypsum-mudstone cycles, which is gypsum bed $\mathrm{G}_{4}$ in the TS section and $\mathrm{G}_{-} 0$ in the $\mathrm{XJ}$ and $\mathrm{SW}$ sections.

few local gypsum beds occur in the TS and Xiejia sections that can not be correlated between the two sections, while Shuiwan lacks gypsum beds in this interval. The top of $\mathrm{G}_{7}$ at $504 \mathrm{~m}$ in the TS section is the most noticeable lithologic boundary (Fig. 1b), marking the top of the thick gypsum beds, while the top of $\mathrm{G}_{4}$ marks the uppermost gypsum bed that is correlatable on a regional scale. This is the bed that 
has previously been linked to climate change associated with the Eocene-Oligocene boundary (Fig. 5; Dupont-Nivet et al., 2007).

The E-O boundary is formally defined at the Global Stratotype Section and Point (GSSP) in the Massignano section, Italy, and corresponds to the extinction of the planktonic foraminiferal Family Hantkeninidae (Premoli Silva and Jenkins, 1993). This event is now being positioned at $\sim 85 \pm 2 \%$ from the base within chron C13r (Pälike et al., 2006; Gradstein et al., 2004). In Fig. 5, the E-O boundary has been plotted in the TS, Shuiwan, and Xiejia sections according to this definition. Remarkably, in all three sections, this level corresponds to the last regional correlatable gypsum bed, $\mathrm{G}_{4}$ in TS and $\mathrm{G}_{-} 0$ in Shuiwan and Xiejia, in accordance to previous estimates (Dupont-Nivet et al., 2007) while the last prominent gypsum bed $\left(\mathrm{G}_{7}\right.$ and $\mathrm{G}_{-} 3$; Fig. 5) occurs three mudstone-gypsum cycles before the E/O boundary. Above the E/O boundary, no gypsum intercalations are observed at a regional scale. Mudstone lithologies do show some paleoenvironmental change for example by better preservation of sedimentary features and occasional occurrence of thin, discontinuous gypsiferous sandstones. In Sect. 5.1, we will further discuss the E/O Climate Transition interval in the Xining Basin records by detailed comparison with open ocean records. The regional basin-wide extent of the gypsum beds indicate that the cycles are likely forced by a stable allogenic mechanism such as orbital forcing of climate indicating that the successions are suitable for cyclostratigraphic analysis.

\section{Cyclostratigraphy}

\subsection{Methods}

The sedimentary cyclicity was studied using high-resolution magnetic susceptibility (MS), median grain size (MGS) and color reflectance $\left(a^{*}\right)$ records. MS of air-dried samples was measured at $10-\mathrm{cm}$ intervals with a Bartington MS2 meter. Grain size was measured at $50-\mathrm{cm}$ intervals with a Malvern Mastersizer-2000 laser particle analyzer, using the pre-treatment techniques recommended by Lu et al. (2002). The color reflectance $\left(L^{*}, a^{*}, b^{*}\right)$ of air-dried powdered samples was measured at $50-\mathrm{cm}$ intervals using a Minolta CM2002 spectrophotometer. Here, we used the $a^{*}$ value (red over green ratio) that clearly follows the observed lithological changes. The AnalySeries 2.0 program (Paillard et al., 1996) was used to perform Gaussian band-pass-filtering. The REDFIT program (Schulz and Mudelsee, 2002) was used to calculate power spectra from unevenly spaced depth and time series with the Lomb-Scargle Fourier Transform using a Welch window. Red-noise boundaries were estimated as upper 80, 90, and 95\% chi-squared limits of a fitted AR1process.

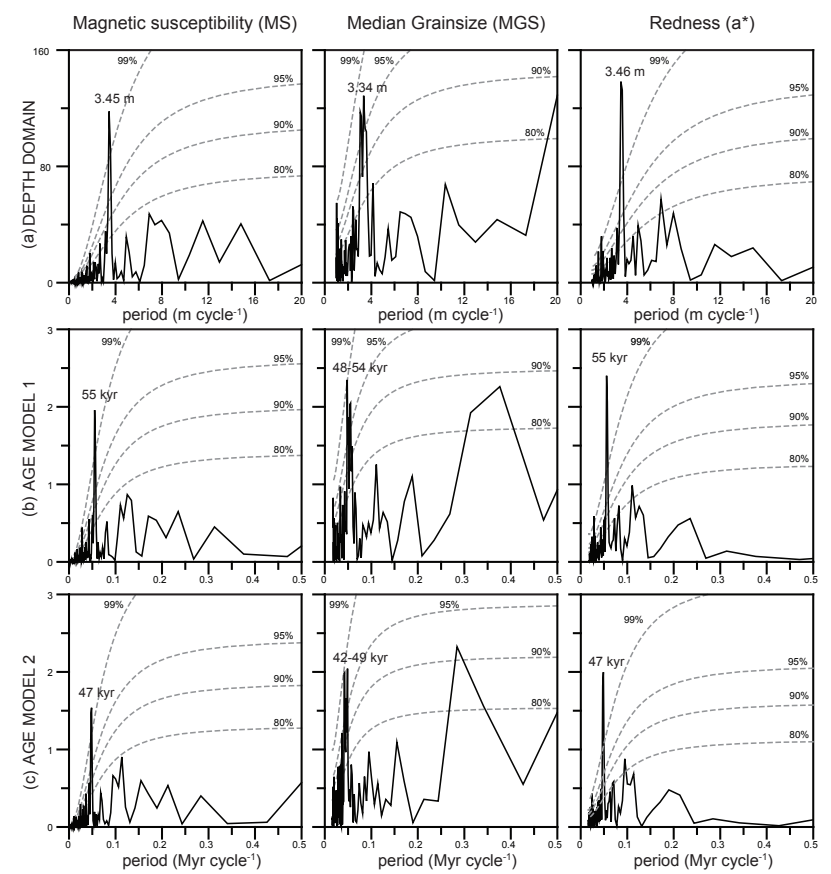

Fig. 6. The Redfit spectral estimates of the magnetic susceptibility (MS), median grain size (MGS), and redness $\left(a^{*}\right)$ in depth domain (a, upper panels) and in time domain against Age Model 1 (b, middle panels) and Age Model 2 (c, lower panels) with their $80 \%$ to 99\% significance levels indicated in grey. Durations of significant spectral peaks are indicated in depth (m) and time (kyr).

\subsection{Time series analysis in depth domain}

The MS, MGS and $a^{*}$ show good correlation with lithologic variations below bed $\mathrm{G}_{4}$ (Fig. 4). High MS, MGS and $a^{*}$ values correspond to red mudstone layers and low values correspond to the intercalated gypsum/gypsiferous layers (Fig. 4). Above bed $\mathrm{G}_{4}$, the MGS record exhibits some low-value intervals that do not correspond to gypsum beds in the stratigraphy (Fig. 4), while the MS and $a^{*}$ records do not show this variability.

To investigate the cyclicity in the TS section, we calculated the red noise power spectra in the depth domain of the MS, MGS, and $a^{*}$ records. The results show a dominant cycle of $\sim 3.3-3.45 \mathrm{~m}$ with confidence levels above 95 to $99 \%$ in the all proxy records (Fig. 6a). This cyclicity corresponds to the basic gypsum-mudstone alternations (Fig. 4). Any other cyclicity, for instance the apparent long cyclicity in the MGS record with a thickness between 10 to $15 \mathrm{~m}$, does not reach the $90 \%$ confidence limit in the red noise spectra (Fig. 6a). Bandpass filtering of the $\sim 3.4-\mathrm{m}$ cycle component indicate that there are around 19 basic cycles in chron $\mathrm{C} 13 \mathrm{r}$ in the TS section, with an estimated uncertainty of 1 cycle. In order to quantify the duration of the basic cyclicity and potentially relate it to orbital forcing, the magnetostratigraphic age model is used. 
Table 1. Published durations of chrons $\mathrm{C} 13 \mathrm{n}$ and $\mathrm{C} 13 \mathrm{r}$ from geologic time scale in black, astronomical calibrations in blue, and radiometric estimates in green. In red, hypothetical duration with obliquity and eccentricity forcing of basic cyclicity in the Tashan section is given. CK95 for Cande and Kent (1995), GTS04 for Gradstein et al. (2004), Pälike06 for Pälike et al. (2006), Jovane06 for Jovane et al. (2006), Gale06 for Gale et al. (2006), Brown09 for Brown et al. (2009), Hyland09 for Hyland et al. (2009), HK09-SP90 for Hilgen and Kuiper (2009) option Swisher and Prothero (1990), HK09-Obrad95 for Hilgen and Kuiper (2009) option Obradovich 1995. For the latter two studies recalculated ages using 28.201 Ma age for the FCT standard, although using different ages for this standard does not influence the durations very much.

\begin{tabular}{|c|c|c|c|c|c|c|c|c|c|c|c|}
\hline $\begin{array}{l}\text { Study } \\
\rightarrow \text { Chron }\end{array}$ & CK95 & GTS04 & Pälike06 & Jovane 06 & Gale06 & Brown09 & Hyland09 & HK09-SP90 & HK09-Obrad95 & $\begin{array}{l}\text { Obliquity- } \\
\text { forcing }\end{array}$ & $\begin{array}{l}\text { Eccentricity- } \\
\text { forcing }\end{array}$ \\
\hline $\mathrm{C} 13 \mathrm{n}$ & 0.493 & 0.518 & 0.473 & - & & - & 0.52 & - & - & - & - \\
\hline $\mathrm{C} 13 \mathrm{r}$ & 1.126 & 1.044 & 1.421 & 1.014 & 0.95 & 0.99 & - & 0.92 & 0.88 & $0.74-0.82$ & $1.80-2.00$ \\
\hline
\end{tabular}

\subsection{Time domain analysis, obliquity, and duration of C13r}

Various chron ages and durations have been proposed in the interval considered (Table 1) and a robust orbitally-tuned time scale is still under construction. A preliminary age model (Age Model 1) is constructed using the GTS04 ages of Gradstein et al. (2004) for the top and base of chron C13n and the top of chron $\mathrm{C} 15 \mathrm{n}$. In this age model, the ages for the base of chron C15n and top of C16n.1n are not included in order to avoid unnecessary uncertainties, because polarity time scales are quite different for this short interval of time (Pälike et al., 2006; Hilgen and Kuiper, 2009). The resulting Redfit power spectra indicate that the basic 3.4-m cyclicity corresponds to a 48 to $55-\mathrm{kyr}$ period (Fig. 6b). This duration is closer to the 41-kyr period of obliquity than to eccentricity forcing for this interval, which was suggested before as driving mechanism on the basis of qualitative data from the Shuiwan section that extended further down into the Eocene (Dupont-Nivet et al., 2007). Eccentricity forcing of the basic cyclicity would result in a $\sim 2$ Myr duration of chron $\mathrm{C} 13 \mathrm{r}$ (Table 1). This is in contrast with all other proposed polarity time scales and would require unlikely high variations in plate tectonic spreading rates deduced from marine magnetic anomaly profiles (D. Wilson, personal communication, 2009). However, obliquity-driven cyclicity in our section is in good agreement with constant seafloor spreading rates, even though it implies shorter $\mathrm{C} 13 \mathrm{r}$ duration in the order of 0.8 to 0.9 Myr.

Obliquity forcing of the basic cyclicity in the Tashan section results in an approximate duration of C13r that is $\sim 200$ kyr shorter than in the GTS04 time scale (Table 1) and than astronomical calibrations at Massignano, Italy (Jovane et al., 2006; Brown et al., 2009), 150 kyr shorter than astronomical calibration at Isle of Wight (Gale et al., 2006), and $\sim 100 \mathrm{kyr}$ shorter than compared to the radiometric age constraints from intercalated ash layers in continental successions in Wyoming, USA (Hilgen and Kuiper, 2009). The latter duration is used in our preferred age model (Age Model 2; see Supplementary Fig. S1) in combination with the existing astronomically-tuned ages for C13n of Pälike et al. (2006).
Note that the astronomical ages of Pälike et al. (2006) for the latest Eocene are not used here, as these were considered preliminary and subject of change (Heiko Pälike, personal communication, 2009). The Redfit power spectra of this Age Model 2 time series indicate a $42 \mathrm{kyr}$ to $49 \mathrm{kyr}$ duration for the basic cyclicity in the TS section (Fig. 6c), in close agreement with the 41-kyr obliquity period.

We argue that 41-kyr obliquity forcing is the most likely allogenic mechanism behind the basic mudstone-gypsum cycles in the Late Eocene infill of the Xining Basin, despite the remaining discrepancies between existing time scales and astronomically-tuned estimates for the duration of C13r. This interpretation is based on the following arguments: (1) the regularity of the basic cycle over more than 1 million year, (2) the lateral consistency of the stratigraphy over more than $15 \mathrm{~km}$, (3) the estimated duration close to the periodicity of the obliquity cycle, and (4) radiometric age constraints in continental successions in Wyoming also suggesting a shorter duration of $\mathrm{C} 13 \mathrm{r}$ than in current time scales (see Table 1).

Cycle counting in the Tashan section is probably a minimum estimate as it is expected that above the regular gypsum-mudstone cycling sedimentation rates might have gone down and cycles are missed in this interval. Therefore, we constructed a last age model (Age Model 3) that tries to adjust for this minimal estimate (Fig. S1). Age Model 3 includes the same age tie-points as Age Model 2 for C13n and top of $\mathrm{C} 15 \mathrm{n}$ and adds two hypothetical obliquity cycles in $\mathrm{C} 13 \mathrm{r}$, one between $\mathrm{G}_{7}$ and $\mathrm{G}_{6}$ and one between $\mathrm{G}_{4}$ and the base of chron C13n (Fig. S1). This age model thus does not result in a different length of $\mathrm{C} 13 \mathrm{r}$, but slightly modifies the relative position of the upper part of the stratigraphy as it is expected that cycles are missed there. Finally, a robust astronomical tuning may come out of IODP Leg 320 in the equatorial Pacific (PEAT) as continuous carbonate-rich successions have been recovered that include the EOT. A robust time scale for this interval is needed to check our age models for the Tashan section. Until then, we regard the radiometric estimates from the continental succession in Wyoming as the most reliable indicators of the duration of $\mathrm{C} 13 \mathrm{r}$. 


\section{Discussion}

\subsection{Obliquity domination of the latest Eocene}

Astronomical forcing of climate dominated by obliquity is expected at times of low eccentricity values mainly related to the long-period 2.4-Myr eccentricity cycle (Hilgen et al., 2000; Hyland et al., 2009) and at times of strong highlatitude climate change supposedly occurring during phases of incipient continental ice sheets at high latitudes (Pälike et al., 2001; Westerhold et al., 2005; Holbourn et al., 2007; Westerhold and Röhl, 2009). A minimum of the 2.4-Myr eccentricity cycle occurs at $\sim 33.6 \mathrm{Ma}$, which is above the interval that shows obliquity dominated cyclicity. Therefore, it seems more likely that a phase of incipient ice sheets preceding the Eocene-Oligocene Transition was causing the strong obliquity forcing of climate in the Xining Basin.

The imprint of the obliquity cycle is apparent in most geological records in which astronomical climate forcing has been detected since the EOT (e.g. Shackleton et al., 1999; Abels et al., 2007; Pälike et al., 2006; Raymo et al., 2006). Before Late Eocene times, however, the dominant cycles seem to be precession and eccentricity with no apparent obliquity component (e.g. Herbert and Fischer, 1986; Gale et al., 1999; Lourens et al., 2005; Westerhold et al., 2007; Westerhold and Röhl, 2009). This supports the idea that the occurrence of dominant obliquity-paced cyclicity in geological records outside intervals of long-period eccentricity minima is related to the presence or development of high-latitude continental ice volume. Westerhold and Röhl (2009) find an interval of $\sim 800 \mathrm{kyr}$ within chron C22r ( $\sim 50 \mathrm{Ma})$ in Demerara Rise sediments of ODP Site 1258, which is dominated by obliquity induced cyclicity. This interval seems to coincide with low eccentricity values related to long-period eccentricity (despite uncertainties in the astronomical solution, Laskar et al., 2004), although the obliquity dominance is stronger than in similar low eccentricity intervals above and below. Westerhold and Röhl (2009) tentatively explain the obliquity dominance in this interval by the special orbital configuration with the "very-long" eccentricity minimum and high-amplitude obliquity variations favoring the nucleation of ephemeral ice sheets and/or the formation of extended seaice directly at the end of the Early Eocene Climatic Optimum (EECO).

Obliquity domination of terrestrial records has been reported from early Oligocene stacking of alternating deep and shallow calcic paleosols in Oregon (Retallack, 2007). Also, an Upper Eocene section in Montana suggests obliquity forcing although this section might be too short to establish that obliquity was the main driver (Retallack, 2007). Cyclostratigraphic analysis of the Upper Eocene to Oligocene Solent Group, mainly deposited on coastal plains, indicates strong, 400-kyr eccentricity related sea-level and climate fluctuations (Gale et al., 2006). On top of these major fluctuations they find rather strong obliquity-forced sea-level and climate cycles starting in the latest Eocene. These results suggest that high-latitude ice-volume changes were dominated by long eccentricity and obliquity, as they clearly were during the Oligocene (Pälike et al., 2006; Abels et al., 2007). Clearly, these glacial cycles also exerted an influence on local climate at intermediate latitudes.

In the marine realm, the Umbria-Marche Basin of the northeastern Apennines in central Italy contains a pelagic limestone and marl succession covering the EOT in full extent. Cyclostratigraphic analysis of carbonate content at Monte Cagnero (Italy) points to 400-kyr, 100-kyr eccentricity and 41-kyr obliquity forcing throughout most of the earliest Oligocene, while the latest Eocene seems to lack the obliquity component (Hyland et al., 2009). At Massignano, Jovane et al. (2006) find a 400-kyr eccentricity and 41-kyr obliquity forcing on susceptibility and carbonate content during chron C13r, while the results of Brown et al. (2009) point to 41-kyr obliquity and 100-kyr eccentricity forcing on susceptibility, carbonate content, and bulk sediment $\delta^{18} \mathrm{O}$. These studies thus indicate that obliquity played a (significant) role in regional climate during the late Eocene with associated changes interpreted to have induced enhanced terrigenous supply during wet/warm periods and enhanced productivity during dry/cold periods (Brown et al., 2009). Strong and persistent obliquity-modulation in the late Eocene is also found in $\mathrm{Ca} / \mathrm{Fe}$ records from the ODP Site 1052 (Blake Nose, Atlantic margin of northern Florida), which show a shift from a precession-eccentricity dominated system to an obliquityeccentricity system at around $36.7 \mathrm{Ma}$, i.e. well before the EOT (Pälike et al., 2001). The authors relate this to changes in the ocean circulation system and the dominant climatic regime consistent with the appearance of ice sheets at high latitude.

In summary, we argue here that the strong obliquity cyclicity observed in the Xining Basin outside an interval with low eccentricity values related to the 2.4-Myr cycle is caused by high-latitude ice volume variability influencing climate over central Asia at this time (Fig. 7). In line with previous suggestions, we believe this might be related to incipient ice sheets that are highly susceptible to environmental and climatological changes, and that might have a significant impact on global climate due to their presence-absence behavior.

\subsection{Comparison with open ocean records}

To compare the EOT interval in the Xining Basin with marine records, we recalculated the age scale of the Tanzanian Drilling Project (TDP) and ODP Sites 522, 744, and 1218 to our Age Model 3 using the chron boundaries of $\mathrm{C} 13 \mathrm{n}$ and C15n (Fig. 7).

This comparison indicates that the most pronounced lithofacies change in the Xining Basin, above bed $\mathrm{G}_{7}$ in TS and G_3 in Xiejia and Shuiwan, coincides with the start of the first shift in oxygen isotopes referred to as the "precursor 


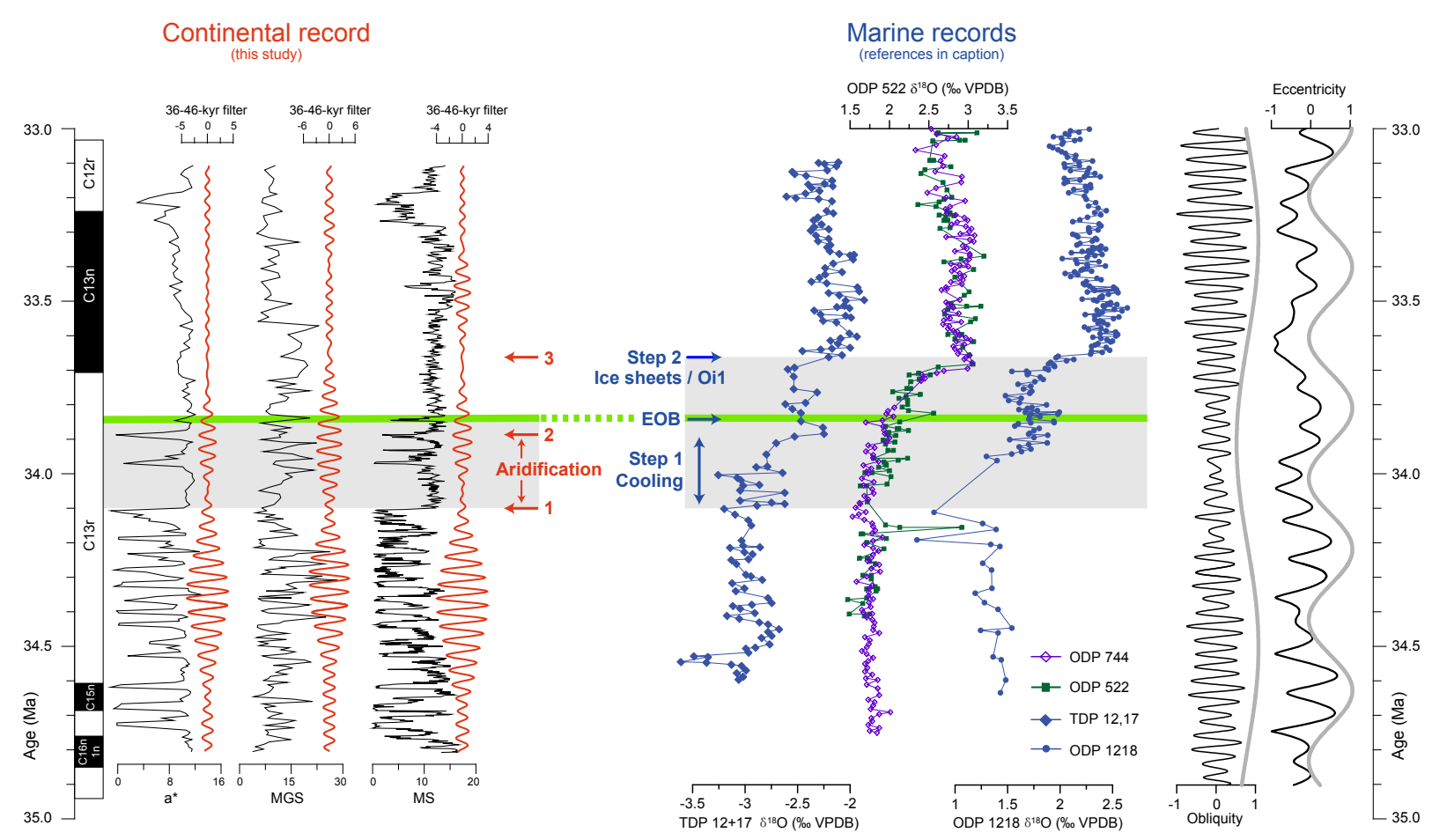

Fig. 7. Left half displays results from the Tashan section in time domain of Age Model 3. From left to right, the magnetostratigraphy (Age model 3), the magnetic susceptibility (MS), redness ( $a^{*}$ ), and median grain size (MGS) proxy records in black with their respective obliquitydomain bandpass filters in red. Event 1 to 3 indicating the last thick regionally correlatable gypsum bed (1), the last regional correlatable gypsum bed (2), and the hypothetical position of Step 2 or Oi-1 isotope event within the terrestrial stratigraphy at which no change has been observed. Right half of figure displays marine oxygen isotope records from the Tanzanian Drilling Project (TDP; Lear et al., 2008; Pearson et al., 2008) and ODP Sites 522, 744 (Zachos et al., 1996), and 1218 (Coxall et al., 2005) against our Age Model 3. Indicated are Step 1 phase, the Eocene Oligocene Boundary (EOB), and Step 2, as recognized within the TDP records. To the right, in black astronomical curves for obliquity and eccentricity from the La2004 (1,1) solution (Laskar et al., 2004) with in grey bandpass filters showing the 1.2-Myr cycle in obliquity and 405-kyr cycle in eccentricity.

event", "EOT-1", and "Step 1" in the marine realm (Coxall et al., 2005; Katz et al., 2008; Lear et al., 2008; Pearson et al., 2008), while the last regionally correlatable gypsum bed corresponds to the end of this first step. Within Age Model 2 this comparison is nearly similar with both events in the Tashan section correlating slightly higher with respect to the marine events. In contrast, the base of the Oi-1 oxygen isotope excursion or Step 2, which is recognized as the main Antarctic ice volume increase event and associated global sea-level lowering seems to have no expression in the Xining Basin. Step 2 is expected in C13n about $20 \%$ above the base of this chron (Fig. 7; Coxall and Pearson, 2007), but no lithological changes are observed in the Xining records at this level. The Median Grain Size (MGS) record does show a decrease though higher than the estimated position of Step 2 (Fig. 7). Additional sedimentological investigations are needed in order to interpret the paleoenvironmental implication of this change in MGS and to find out whether the mudstone depositional environment differed in the early Oligocene from the latest Eocene.
The disappearance of regionally correlatable gypsum and gypsiferous beds at the top of $\mathrm{G}_{4}$ has been interpreted as to reflect regional aridification by Dupont-Nivet et al. (2007). This interpretation is based on the fact that the gypsum deposits represent the wettest facies with respect to the dry mudflat environments during red mudstone deposition and disappearance of the wettest facies might indicate a general aridification. The major reduction in thickness of intercalated gypsum beds at the top of $\mathrm{G}_{7}$ can likewise be interpreted as an aridification step. In the TDP records, Step 1 has been related to a $2.5^{\circ} \mathrm{C}$ equatorial temperature decrease with only minor continental ice volume increases (Lear et al., 2008). These findings are consistent with a temperature drop indicated by an increase in charophyte oogonia size and a minor sea-level drop occurring around $150 \mathrm{kyr}$ before the base of C13n in the Solent Group of the Hampshire Basin in southern England (Gale et al., 2006; see also Hooker et al., 2009). The coincidence of Step 1 with lithofacies changes in the Xining Basin emphasizes the global marine and terrestrial significance of the first step of the EOT, as also suggested by major marine planktonic and benthic extinctions culminating 
just above Step 1 at the EO-boundary (Pearson et al., 2008; EOB in Fig. 7). Coincidence of lithofacies change with first step in oxygen isotope changes, preceding the base of Oi-1 provides a unprecedented teleconnection evidence between continental and marine realms at the EOT. It has been suggested (Dupont-Nivet et al., 2007; Gasse, 2000; Lawrence et al., 2003) that the reported cooling of global ocean temperatures at the EOT (Liu et al., 2009) may generally reduce moisture transport to continental interiors. However, the precise climate-ocean dynamics that could have produced this important global response remain to be tested by climate modeling studies (Zhang et al., 2007; Eldrett et al., 2009).

Dupont-Nivet et al. (2007) proposed two mechanisms for the aridification in the Xining Basin around the E-O boundary. Firstly, global ocean cooling would reduce precipitation in the continental interiors (Gasse, 2000) and, secondly, glacioeustatic sea-level lowering would cause shoreline retreat of the Paratethys Sea, which may lead to significant increase in the distance of the water vapor source to the Xining Basin. The coincidence of the lithofacies change in the Xining Basin with Step 1 and not Step 2, which is related to the main sea-level lowering event at the EOT, suggests that the Paratethys was not the principal moisture source of the Asian interior. Alternatively, though less likely, the first $15 \mathrm{~m}$ of sea-level lowering estimated for Step 1 could have been the thresh-hold for Paratethys retreat in case the connection with the open ocean of this inland sea was already in a critical state. The coincidence of lithofacies shifts and Step 1, which is characterized by an atmospheric temperature drop (Gale et al., 2006; Lear et al., 2008), would further suggest that Asian paleoenvironmental change also occurred during the first step rather than the second step. This is at odds with the major mammal turnover referred to as the "Grande Coupure" that is reported to occur during the basal parts of $\mathrm{C} 13 \mathrm{n}$ at a major sea level lowstand and is thus equivalent to Step 2 and Oi-1, rather than Step 1 (Hooker et al., 2009). The latter is however perfectly in line with European faunal turnover in reaction to Asian immigration due to the retreat of the marine barrier between Asia and Europe, likely to occur at Step 2 (Dawson, 2003). Dating of the "Mongolian Remodeling" fauna is still insufficient for such detailed comparison with the EOT (Kraatz and Geisler, 2010). In terrestrial records in North America, a net decrease in precipitation and increase in seasonality has been deduced from various sedimentological and paleontological data, while a decrease in mean annual temperature of around $7^{\circ} \mathrm{C}$ is observed based on $\delta^{18} \mathrm{O}$ values of fossil remains (e.g. Zanazzi et al., 2009). Despite these changes, the vast majority of mammal lineages do not show an observable response to the EOT. The age control of these records is not at the resolution to distinguish between Step 1 and Step 2 at the EOT interval. Nevertheless, it seems that the Chadronian-Orellan mammal zone boundary occurs before the major increase in $\delta^{18} \mathrm{O}$ bone carbonate that is correlated to Step 2 and the Oi-1 isotope event (Zanazzi et al., 2009).

\section{Conclusions}

Our magnetostratigraphic age model for the uppermost Eocene to Oligocene terrestrial Tashan section in the Xining Basin, China, suggests that the $\sim 3.4 \mathrm{~m}$ thick basic cyclicity of alternating playa gypsum and dry mudflat red mudstones is controlled by the 41-kyr obliquity cycle driving alternating drier and wetter periods in Asian climate from at least 1 million year before the EOT. Regional correlations to previously studied successions and comparison with marine records suggests that the most pronounced lithofacies change in the Xining Basin corresponds to the first of two widely-recognized steps in oxygen isotopes across the EOT. This first step or "Step 1" that precedes the major, second step (i.e. the base of Oi-1 excursion) has been reported to be mainly related to atmospheric cooling rather than ice volume growth. Coincidence with lithofacies changes in our Chinese record suggests a global atmospheric impact of Step 1, in line with marine plankton extinctions culminating just above the first step at the Eocene-Oligocene boundary. Lack of impact on the Xining Basin record of Step 2 when major ice volume increase and sea-level lowering of the EOT occurred would suggests that Asian climate was not affected by this event and that Paratethys Sea retreat would be a less obvious candidate as aridification mechanism for Asian climate at the EOT. These correlations imply that atmospheric impact and cooling of the EOT occurred at Step 1.

\section{Supplementary material related to this article is available online at: http://www.clim-past.net/6/501/2010/ cp-6-501-2010-supplement.zip.}

Acknowledgements. This study is supported by the National Natural Science Foundation of China (projects 40730104), the Chinese Academy of Sciences (KZCX2-YW-117), the Project for Basic Research (2004CB720203), and the Foundation of Geological Survey of China (1212010610103). H. A. and G. D.N. thank the Netherlands Organisation for Scientific Research (NWO-ALW) for funding. We thank Zhengtang Guo, Qiuzhen Yin, A. Julia Kahmann, Qingzhen Hao, Shuzhen Peng, Chuang Xuan and Tao Zhan for helpful discussions and suggestions. We are grateful to Chenxi $\mathrm{Xu}$ and Chunlin $\mathrm{Wu}$ for field assistance and to Mingying Liang, Dongdong Chen, Lijuan Zhang and Lijun Zhu for laboratory assistance. We thank Paul Pearson for providing the Tanzanian Drilling Project data against MCD scale.

Edited by: M.-F. Loutre 


\section{References}

Abels, H. A., Simaeys, S. V., Hilgen, F. J., Man, E. D., and Vandenberghe, N.: Obliquity-dominated glacio-eustatic sea level change in the early Oligocene: evidence from the shallow marine siliciclastic Rupelian stratotype (Boom Formation, Belgium), Terra Nova, 19(1), 65-73, 2007.

Brown, R. E., Koeberl, C., Montanari, A., and Bice, D. M.: Evidence for a change in Milankovitch forcing caused by extraterrestrial events at Massignano, Italy, Eocene-Oligocene boundary GSSP, in: The Late Eocene Earth: Hothouse, Icehouse, and Impacts, edited by: Koeberl, C. and Montanari, A., Geol. Soc. Spec. Publ., 452, 119-137, 2009.

Cande, S. C. and Kent, D. V.: Revised calibration of the geomagnetic polarity timescale for the Late Cretaceous and Cenozoic, J. Geophys. Res., 100(B4), 6093-6095, 1995.

Coxall, H. K. and Pearson, P. N.: The Eocene-Oligocene transition, in: Deep-Time Perspectives on Climate Change: Marrying the Signal from Computer Models and Biological Proxies, edited by: Williams, M., Haywood, A. M., Gregory, F. J., and Schmidt, D. N., Micropalaeonto. Soc. Spec. Publ., The Geological Society, London, 351-387, 2007.

Coxall, H. K., Wilson, P. A., Pälike, H., Lear, C. H., and Backman, J.: Rapid stepwise onset of Antarctic glaciation and deeper calcite compensation in the Pacific Ocean, Nature, 433, 53-57, 2005.

Dai, S., Fang, X. M., Dupont-Nivet, G., Song, C., Gao, J., Krijgsman, W., Langereis, C., and Zhang, W.: Magnetostratigraphy of Cenozoic sediments from the Xining Basin: Tectonic implications for the northeastern Tibetan Plateau, J. Geophys. Res., 111, B11102, doi:10.1029/2005JB004187, 2006.

Dawson, M. R.: Paleogene rodents in Eurasia, in: Distribution and migration of Tertiary mammals in Eurasia, edited by: Reumer, J. W. F. and Wessels, W., Deinsea, 10, 97-126, 2003.

DeConto, R. M. and Pollard, D.: Rapid Cenozoic glaciation of Antarctica induced by declining atmospheric $\mathrm{CO}_{2}$, Nature, 421, 245-249, 2003.

DeConto, R. M., Pollard, D., Wilson, P. A., Pälike, H., Lear, C. H., and Pagani, M.: Thresholds for Cenozoic bipolar glaciation, Nature, 455, 652-656, 2008.

Dupont-Nivet, G., Horton, B. K., Butler, R. F., Wang, J., Zhou, J., and Waanders, G. L.: Paleogene clockwise tectonic rotation of the Xining-Lanzhou region, northeastern Tibetan Plateau, J. Geophys. Res., 109, B04401, doi:04410.01029/02003JB002620, 2004.

Dupont-Nivet, G., Krijgsman, W., Langereis, C. G., Abels, H. A., Dai, S., and Fang, X. M.: Tibetan plateau aridification linked to global cooling at the Eocene - Oligocene transition, Nature, 445, 635-638, 2007.

Eldrett, J. S., Greenwood, D. R., Harding, I. C., and Huber, M.: Increased seasonality through the Eocene to Oligocene transition in northern high latitudes, Nature, 459, 969-973, 2009.

Gale, A. S., Huggett, J. M., Pälike, H., Laurie, E., Hailwood, E. A., and Hardenbol, J.: Correlation of Eocene-Oligocene marine and continental records: orbital cyclicity, magnetostratigraphy and sequence stratigraphy of the Solent Group, Isle of Wight, UK, J. Geol. Soc., 163(2), 401-415, 2006.

Gale, A. S., Young, J. R., Shackleton, N. J., Crowhurst, S. J., and Wray, D. S.: Orbital tuning of Cenomanian marly chalk successions: towards a Milankovitch time-scale for the Late Cre- taceous, Phil. Trans. R. Soc. Lond. A., 357, 1815-1829, 1999.

Gasse, F.: Hydrological changes in the African tropics since the Last Glacial Maximum, Quaternary Sci. Rev., 19, 189-211, 2000.

Gradstein, F. M., Ogg, J. G., and Smith, A. G.: A Geologic Time Scale 2004, Cambridge University Press, Cambridge, 1-589, 2004.

Hansen, T. A., Kelley, P. H., and Haasl, D. M.: Paleoecological patterns in molluscan extinctions and recoveries: comparison of the Cretaceous-Paleogene and Eocene-Oligocene extinctions in North America, Palaeogeogr. Palaeocl., 214, 233-242, 2004.

Herbert, T. D. and Fischer, A. G.: Milankovitch climatic origin of mid-Cretaceous black shale rhythms in central Italy, Nature, 321, 739-743, 1986.

Hilgen, F. J., Bissoli, L., Iaccarino, S., Krijgsman, W., Meijer, R., Negri, A., and Villa, G.: Integrated stratigraphy and astrochronology of the Messinian GSSP at Oued Akrech (Atlantic Morocco), Earth Planet. Sci. Lett., 182, 237-251, 2000.

Hilgen, F. J. and Kuiper, K. F.: A critical evaluation of the numerical age of the Eocene-Oligocene boundary, in: The Late Eocene Earth: Hothouse, Icehouse, and Impacts, edited by: Koeberl, C. and Montanari, A., Geol. Soc. Spec. Publ., 452, 139-148, 2009.

Holbourn, A., Kuhnt, W., Schulz, M., Flores, J.-A., and Andersen, N.: Orbitally-paced climate evolution during the middle Miocene "Monterey" carbon-isotope excursion, Earth Planet. Sci. Lett., 261, 534-550, 2007.

Hooker, J. J., Grimes, S. T., Mattey, D. P., Collinson, M. E., and Sheldon, N. D.: Refined correlation of the UK Late Eocene-Early Oligocene Solent Group and timing of its climate history, in: The Late Eocene Earth: Hothouse, Icehouse, and Impacts, edited by: Koeberl, C. and Montanari, A., Geol. Soc. Spec. Publ., 452, 179195, 2009.

Horton, B. K., Dupont-Nivet, G., Zhou, J., Waanders, G. L., Butler, R. F., and Wang, J.: Mesozoic-Cenozoic evolution of the XiningMinhe and Dangchang basins, northeastern Tibetan Plateau: Magnetostratigraphic and biostratigraphic results, J. Geophys. Res., 109, B04402, doi:04410.01029/02003JB002913, 2004.

Hyland, E., Murphy, B., Varela, P., Marks, K., Colwell, L., Tori, F., Monechi, S., Cleaveland, L., Brinkhuis, H., Van Mourik, C. A., Coccioni, R., Bice, D., and Montanari, A.: Integrated stratigraphic and astrochronologic calibration of the EoceneOligocene transition in the Monte Cagnero section (northeastern Apennines, Italy): A potential parastratotype for the Massignano global stratotype section and point (GSSP), in: The Late Eocene Earth: Hothouse, Icehouse, and Impacts, edited by: Koeberl, C. and Montanari, A., Geol. Soc. Spec. Publ., 452, 303-322, 2009.

Ivany, L. C., Nesbitt, E. A., and Prothero, D. R.: The Marine Eocene-Oligocene Transition: A Synthesis, in: From Greenhouse to Icehouse: The Marine Eocene-Oligocene Transition, edited by: Prothero, D. R., Ivany, L. C., and Nesbitt, E. A., Columbia University Press, New York, 522-534, 2003.

Jovane, L., Florindo, F., Sprovieri, M., and Pälike, H.: Astronomic calibration of the late Eocene/early Oligocene Massignano section (central Italy), Geochem. Geophys. Geosyst., 7, Q07012, doi:10.1029/2005GC001195, 2006.

Katz, M. E., Miller, K. G., Wright, J. D., Wade, B. S., Browning, J. V., Cramer, B. S., and Rosenthal, Y.: Stepwise transition from the Eocene greenhouse to the Oligocene icehouse, Nature Geosci., 1, 329-334, 2008. 
Kirschvink, J. L.: The least-squares line and plane and the analysis of palaeomagnetic data, Geophys. J. R. Astron. Soc., 62, 699$718,1980$.

Kraatz, B. P. and Geisler, J. H.: Eocene-Oligocene transition in Central Asia and its effects on mammalian evolution, Geology, 38(2), 111-114, 2010.

Laskar, J., Robutel, P., Joutel, F., Gastineau, M., Correia, A. C. M., and Levrard, B.: A long-term numerical solution for the insolation quantities of the Earth, Astron. Astrophys., 428, 261-285, 2004.

Lawrence, K. T., Sloan, L. C., and Sewall, J. O.: Terrestrial climatic response to precessional orbital forcing in the Eocene, in: Causes and Consequences of Globally Warm Climates in the Early Paleogene, edited by: Wing, S. L., Gingerich, P. D., Schmitz, B., and Thomas, E., Geol. Soc. Spec. Publ., 369, 65-77, 2003.

Lear, C. H., Bailey, T. R., Pearson, P. N., Coxall, H. K., and Rosenthal, Y.: Cooling and ice growth across the Eocene-Oligocene transition, Geology, 36(3), 251-254, 2008.

Lear, C. H., Elderfield, H., and Wilson, P. A.: Cenozoic deepsea temperatures and global ice volumes from $\mathrm{Mg} / \mathrm{Ca}$ in benthic foraminiferal calcite, Science, 287, 269-272, 2000.

Liu, Z. H., Pagani, M., Zinniker, D., DeConto, R., Huber, M., Brinkhuis, H., Shah, S. R., Leckie, R. M., and Pearson, A.: Global cooling during the Eocene-Oligocene climate transition, Science, 323, 1187-1190, 2009.

Lourens, L. J., Sluijs, A., Kroon, D., Zachos, J. C., Thomas, E., Rohl, U., Bowles, J., and Raffi, I.: Astronomical pacing of late Palaeocene to early Eocene global warming events, Nature, 435, 1083-1087, 2005.

Lu, H. Y., Miao, X. D., and Sun, Y. B.: Pretreatment methods and their influences on grain-size measurement of aeolian 'Red Clay' in North China, Mar. Geol. Quaternary Geol., 22(3), 129-135, 2002 (in Chinese with English abstract).

McFadden, P. L. and McElhinny, M. W.: Classification of the reversal test in palaeomagnetism, Geophys. J. Int., 103, 725-729, 1990.

Meng, J. and McKenna, M. C.: Faunal turnovers of Palaeogenemammals from the Mongolian Plateau, Nature, 394, 364-367, 1998.

Miller, K. G., Wright, J. D., and Fairbanks, R. G.: Unlocking the ice house: Oligocene-Miocene oxygen isotopes, eustasy, and margin erosion, J. Geophys. Res., 96(B4), 6829-6848, 1991.

Obradovich, J. D., Evanoff, E., and Larson, E. E.: Revised singlecrystal laser-fusion 40Ar/39Ar ages of Chadronian tuffs in the White River Formation of Wyoming, Geological Society of America Abstracts with Programs, 27(3), A-77, 1995.

Pälike, H., Norris, R. D., Herrle, J. O., Wilson, P. A., Coxall, H. K., Lear, C. H., Shackleton, N. J., Tripati, A. K., and Wade, B. S.: The heartbeat of the Oligocene climate system, Science, 314 , 1894-1898, 2006.

Pälike, H., Shackleton, N. J., and Röhl, U.: Astronomical forcing in Late Eocene marine sediments, Earth Planet. Sci. Lett., 193, 589-602, 2001.

Paillard, D., Labeyrie, L., and Yiou, P.: Macintosh program performs time-series analysis, EOS, Trans. Am. Geophys. Un., 77(39), 379, 1996.

Pearson, P. N., Foster, G. L., and Wade, B. S.: Atmospheric carbon dioxide through the Eocene-Oligocene climate transition, Nature, 461, 1110-1113, 2009.
Pearson, P. N., McMillan, I. K., Wade, B. S., Jones, T. D., Coxall, H. K., Bown, P. R., and Lear, C. H.: Extinction and environmental change across the Eocene-Oligocene boundary in Tanzania, Geology, 36(2), 179-182, 2008.

Pearson, P. N. and Palmer, M. R.: Atmospheric carbon dioxide concentrations over the past 60 million years, Nature, 406, 695-699, 2000.

Premoli Silva, I. and Jenkins, G.: Decision on the EoceneOligocene boundary stratotype, Episodes, 16(3), 379-382, 1993.

Qinghai Bureau of Geology and Mineral Resources: Geologic maps of the Duoba, Gaodian, Tianjiazai, and Xining regions (4 sheets), with regional geologic report (1:50000 scale), Geological Publishing House, Beijing, 1985 (in Chinese).

Raymo, M. E., Lisiecki, L. E., and Nisancioglu, K. H.: PlioPleistocene ice volume, Antarctic climate, and the global $\delta^{18} \mathrm{O}$ record, Science, 313, 492-495, 2006.

Retallack, G. J.: Cenozoic Paleoclimate on Land in North America, J. Geol., 115, 271-294, 2007.

Retallack, G. J., Orr, W. N., Prothero, D. R., Duncan, R. A., Kester, P. R., and Ambers, C. P.: Eocene-Oligocene extinction and paleoclimatic change near Eugene, Oregon, Geol. Soc. Am. Bull., 116(7/8), 817-839, 2004.

Schouten, S., Eldrett, J., Greenwood, D. R., Harding, I., Baas, M., and Sinnighe Damsté, J. S.: Onset of long-term cooling of Greenland near the Eocene-Oligocene boundary as revealed by branched tetraether lipids, Geology, 36(2), 147-150, 2008.

Schulz, M. and Mudelsee, M.: REDFIT: estimating red-noise spectra directly from unevenly spaced paleoclimatic time series, Comput. Geosci., 28, 421-426, 2002.

Shackleton, N. J., Crowhurst, S. J., Weedon, G., and Laskar, L.: Astronomical calibration of Oligocene-Miocene time, Phil. Trans. R. Soc. Lond. A, 357, 1907-1929, 1999.

Swisher III, C. C. and Prothero, D. R.: Single-crystal ${ }^{40} \mathrm{Ar} /{ }^{39} \mathrm{Ar}$ dating of the Eocene-Oligocene Transition in North America, Science, 249, 760-762, 1990.

Tauxe, L.: Paleomagnetic Principles and Practice, Kluwer Academic Publishers, Dordrecht, 1-299, 1998.

Tripati, A., Backman, J., Elderfield, H., and Ferretti, P.: Eocene bipolar glaciation associated with global carbon cycle changes, Nature, 436, 341-346, 2005.

Westerhold, T., Bickert, T., and Röhl, U.: Middle to late Miocene oxygen isotope stratigraphy of ODP site 1085 (SE Atlantic): new constrains on Miocene climate variability and sea-level fluctuations, Palaeogeogr. Palaeocl., 217, 205-222, 2005.

Westerhold, T., Röhl, U., Laskar, J., Raffi, I., Bowles, J., Lourens, L. J., and Zachos, J. C.: On the duration of magnetochrons $\mathrm{C} 24 \mathrm{r}$ and $\mathrm{C} 25 \mathrm{n}$ and the timing of early Eocene global warming events: Implications from the Ocean Drilling Program Leg 208 Walvis Ridge depth transect, Paleoceanography, 22, PA2201, doi:10.1029/2006PA001322, 2007.

Westerhold, T. and Röhl, U.: High resolution cyclostratigraphy of the early Eocene - new insights into the origin of the Cenozoic cooling trend, Clim. Past, 5, 309-327, doi:10.5194/cp-5-3092009, 2009.

Zachos, J., Pagani, M., Sloan, L., Thomas, E., and Billups, K.: Trends, rhythms, and aberrations in global climate $65 \mathrm{Ma}$ to present, Science, 292, 686-693, 2001.

Zachos, J. C., Quinn, T. M., and Salamy, K. A.: High-resolution $\left(10^{4}\right.$ years $)$ deep-sea foraminiferal stable isotope records of the 
Eocene-Oligocene climate transition, Paleoceanography, 11(3), 251-266, 1996.

Zanazzi, A., Kohn, M. J., and Terry Jr., D. O.: Biostratigraphy and paleoclimatology of the Eocene-Oligocene boundary section at Toadstool Park, northwestern Nebraska, USA, in: The Late Eocene Earth: Hothouse, Icehouse, and Impacts, edited by: Koeberl, C. and Montanari, A., Geol. Soc. Spec. Publ., 452, 197-214, 2009.
Zhai, Y. P. and Cai, T. L.: The Tertiary system of Gansu province, Gansu Geol., 2, 1-40, 1984 (in Chinese).

Zhang, Z. S., Wang, H. J., Guo, Z. T., and Jiang, D. B.: Impacts of tectonic changes on the reorganization of the Cenozoic paleoclimatic patterns in China, Earth Planet. Sci. Lett., 257, 622-634, 2007. 